\title{
Increased fertility in young primiparous female bank voles, Clethrionomys glareolus, treated with prolactin or progesterone after mating
}

\author{
Lilian M. Westlin \\ Department of Zoology, University of Lund, S-22362 Lund, Sweden
}

\begin{abstract}
Summary. Fertility in young primiparous female bank voles was improved by daily injections after mating of progesterone $(0.5 \mathrm{mg} /$ day) or prolactin ( $8 \mathrm{i}$.u./day). Prolactin treatment increased the number of healthy corpora lutea. The results suggest that the sterile matings at the start of the breeding season are not due to failure of ovulation, but to lack of progesterone from inactive CL.
\end{abstract}

\section{Introduction}

Female bank voles, Clethrionomys glareolus, which are induced ovulators (Clarke, Clulow \& Greig, 1970; Westlin \& Nyholm, 1982), have several matings at the start of the breeding season that do not result in pregnancy (Westlin \& Nyholm, 1982). The corpora lutea (CL) of these sterile matings differ from CL of pregnancy in that they are smaller, less luteinized (as judged from their smaller cell size) and have a short life span (Westlin \& Nyholm, 1982). Milligan (1975) found short-lived CL in field voles, Microtus agrestis, after limited matings and after hormonally induced ovulations, and that the life span of these CL can be prolonged by exogenous prolactin (Charlton, Milligan \& Versi, 1978). In field voles the development of functional CL after mating was associated with elevated prolactin levels immediately following coitus (Milligan \& MacKinnon, 1976). Prolactin levels were also elevated 4 days after mating in animals with active CL. The present study was undertaken to examine whether the fertility of young female bank voles could be increased by progesterone treatment (as replacement for the inadequate CL) or by exogenous prolactin (to stimulate the CL).

\section{Material and Methods}

Animals. The bank voles, Clethrionomys glareolus, were bred in the Department of Zoology, University of Lund, and maintained as described by Gustafsson, Andersson \& Westlin (1980).

Females were weaned at 16 days of age and kept in single-sex groups. When 30 days old, the females were isolated, and given mating tests. Males used as studs were $>2$ months old. The mating procedure was as follows. A male was introduced into the female's cage at 09:00 h, and the female was checked every $2 \mathrm{~h}$ for a copulatory plug or for mating behaviour. After mating, the male was removed. If no mating occurred during the day, the male was removed and the test was repeated the following day. Females which had not mated when 2 months old were discarded.

Injections. These were given subcutaneously under very light ether anaesthesia beneath the 
skin at the back of the head. All injection volumes were $0.1 \mathrm{ml}$. Progesterone (AB LEO, Helsingborg, Sweden) was made up in sesame oil and administered at a dose of $0.5 \mathrm{mg}$ per injection. Prolactin (ovine prolactin, Sigma Chemical Company) was injected in doses of $0.25,1$ or 4 i.u. per injection. The vehicle was a solution of $3 \mathrm{mg}$ phenol and $50 \mathrm{mg}$ glucose per $\mathrm{ml}$ distilled water. Control females were injected with sesame oil only.

Experimental methods. After mating the females were randomly assigned to different treatments (see Table 1). Group A was given only sesame oil once a day for 5 days starting $24 \mathrm{~h}$ after mating. Group B was given $0.5 \mathrm{mg}$ progesterone/day in the same manner as Group A. In Groups C, D and E prolactin was given every $12 \mathrm{~h}$ for 5 days starting $12 \mathrm{~h}$ after mating, the total daily dose being $0.5,2$ or 8 i.u. per animal. All animals were killed 6 days after mating, a time when embryos easily can be detected in the uteri as 3-4-mm swellings. At autopsy all ovaries and uteri were examined macroscopically for the presence of large pink CL and embryos respectively, dissected out, fixed in Bouin's fluid, and routinely embedded in paraffin wax. The ovaries were serially sectioned at $7 \mu \mathrm{m}$ and stained with a tetrachrome combination according to Borg, Andersson \& Meurling (1978). Histologically, two types of CL were distinguished: (1) large CL with large well luteinized cells and richly vascularized, and (2) small CL with cells containing pycnotic nuclei and degenerated cytoplasm and poorly vascularized (see Westlin \& Nyholm, 1982).

\section{Results and Discussion}

The ages at mating were similar in all groups, except in Group B in which most of the females were very young when they mated. No relationship between age at mating and fertility was seen. Following mating, all the females in each group possessed $\mathrm{CL}$, confirming that the infertile matings were not caused by failure of ovulation. In control females (Group A) only a small proportion $(35 \%)$ of the females became pregnant; the non-pregnant females did not have functional CL. In contrast, progesterone treatment after mating (Group B) resulted in pregnancy in all females, suggesting that the infertility following mating was not the result of any incompetence in the gametes following induced ovulation or failure of fertilization, but rather was due to the lack of progesterone from the short-lived CL. Progesterone treatment itself did not stimulate the development of luteal function: the proportion of pregnant females with healthy CL did not differ from the controls (Table 1). This suggests that progesterone feedback alone is not sufficient to stimulate the luteotrophic system. The results after prolactin administration

Table 1. The effect (at Day 6) of daily injections of progesterone and twice daily injections of prolactin on fertility and the function of corpora lutea in mated, primiparous female bank voles

\begin{tabular}{|c|c|c|c|c|c|}
\hline \multirow[b]{2}{*}{ Group } & \multirow[b]{2}{*}{$\begin{array}{l}\text { No. of } \\
\text { females }\end{array}$} & \multirow[b]{2}{*}{ Treatment } & \multicolumn{3}{|c|}{ No. of females } \\
\hline & & & $\begin{array}{c}\text { With } \\
\text { degenerate } \\
\text { CL }\end{array}$ & $\begin{array}{c}\text { With healthy } \\
\text { CL } \\
(\%)\end{array}$ & $\begin{array}{l}\text { Pregnant } \\
\text { (\%) }\end{array}$ \\
\hline A & 20 & Sesame oil & 13 & $7(35)$ & $7(35)$ \\
\hline B & 20 & Progesterone & 13 & $7(35)$ & $20(100)^{a, c}$ \\
\hline $\mathrm{C}$ & 15 & Prolactin, 0.5 i.u./day & 10 & $5(33)$ & $5(33)$ \\
\hline $\mathrm{D}$ & 15 & Prolactin, 2 i.u./day & 7 & $8(53)$ & $8(53)$ \\
\hline $\mathrm{E}$ & 15 & Prolactin, 8 i.u./day & 1 & $14(93)^{\mathbf{a}, b, c}$ & $14(93)^{\mathrm{a}, \mathrm{c}}$ \\
\hline
\end{tabular}

Different from Group A, $P<0.05 ; \chi^{2}$ test.

${ }^{b}$ Different from Group B, $P<0.05 ; \chi^{2}$ test.

${ }^{c}$ Different from Group C, $P<0.05 ; \chi^{2}$ test. 
(Groups C, D and E) suggest that the short life of the CL may have been due to inadequate luteotrophic stimuli. In the females injected with different doses of prolactin, the frequency of pregnancy increased with increasing dose (Table 1): a significant effect was obtained with 8 i.u./day, a dose that was higher than that, $0.5 \mathrm{i}$.u./day, which was sufficient to activate the $\mathrm{CL}$ in field voles (Charlton et al., 1978).

These results suggest that the sterile matings occurring in young females and at the start of the breeding season in the field (Westlin \& Nyholm, 1982) reflect the ease of mating to induce ovulation, but the relative lack of effect of copulation in stimulating the luteotrophic mechanism.

I thank Miss Monica Niklasson for technical assistance and AB LEO for progesterone. The study was financed by grants from the Swedish Natural Research Council.

\section{References}

Borg, B., Andersson, M. \& Meurling, P. (1978) The biology of the wild rabbit, Oryctolagus cuniculus, in southern Sweden. III. Histology of the uterus in the non-breeding season. Acta zool., Stockh. 59, 253260.

Charlton, H.M., Milligan, S.R. \& Versi, E. (1978) Studies on the control of the corpus luteum in the vole, Microtus agrestis. J. Reprod. Fert. 52, 283288.

Clarke, J.R., Clulow, F.W. \& Greig, F. (1970) Ovulation in the bank vole, Clethrionomys glareolus. J. Reprod. Fert. 25, 531, Abstr.

Gustafsson, T.O., Andersson, C.B. \& Westlin, L.M. (1980) Reproduction in a laboratory colony of bank voles, Clethrionomys glareolus. Can. J. Zool. 58, 1016-1021.

Milligan, S.R. (1975) Mating, ovulation and corpus luteum function in the vole, Microtus agrestis. $J$. Reprod. Fert. 42, 35-44.

Milligan, S.R. \& MacKinnon, P.C.B. (1976) Correlation of plasma LH and prolactin levels with the fate of the corpus luteum in the vole, Microtus agrestis. $J$. Reprod. Fert. 47, 111-113.

Westlin, L.M. \& Nyholm, E. (1982) Sterile matings initiates the breeding season in the bank vole, Clethrionomys glareolus. A field and laboratory study. Can.J. Zool. 60, 387-391.

Received 2 November 1981 